\title{
OS LIMITES E AS POSSIBILIDADES DO ESTADO-NAÇÃO NA PROMOÇÃO DO TRABALHO DECENTE NO MARCO DA AGENDA 2030 DA ORGANIZAÇÃO DAS NAÇÕES UNIDAS
}

\author{
THE LIMITS AND POSSIBILITIES OF THE NATION-STATE \\ IN PROMOTING DECENT WORK AT THE UNITED NATIONS \\ AGENDA 2030
}

\section{LOS LÍMITES Y LAS POSIBILIDADES DEL ESTADO-NACIÓN EN LA PROMOCIÓN DEL TRABAJO DIGNO EN EL MARCO DE LA AGENDA 2030 DE LAS NACIONES UNIDAS}

Giovanni Olsson* Tuana Paula Lavall*

\begin{abstract}
1 Introdução. $2 \mathrm{O}$ trabalho decente enquanto vetor de desenvolvimento sustentável. 2.1 Aportes para uma definição de trabalho decente. $2.2 \mathrm{O}$ trabalho decente na Agenda 2030 da ONU e os desafios contemporâneos do mundo do trabalho. 3 O papel do Estado-Nação na afirmação do trabalho decente. 4 Conclusão. Referências.
\end{abstract}

\section{RESUMO}

A Organização das Nações Unidas (ONU), em seu mais recente projeto de governança global, vislumbra, na realização equilibrada de objetivos sociais, econômicos, ambientais e políticos, a chave para o desenvolvimento planetário em condições de sustentabilidade. $\mathrm{O}$ trabalho decente, pelo potencial emancipatório e afirmador da dignidade humana que apresenta, desempenha papel estratégico nesse processo, merecendo menção no oitavo Objetivo de Desenvolvimento Sustentável (ODS). Nesse sentido, o presente artigo verifica quais são os limites e as possibilidades do Estado-nação na efetivação do trabalho decente no âmbito da Agenda 2030 das Nações Unidas, o que se dá por meio de pesquisa bibliográfica, adotando o método dedutivo. Os resultados indicam que, embora o Estado-nação possa avançar na efetivação do

* Doutor em Direito (UFSC). Professor do PPG em Direito da Universidade Comunitária da Região de Chapecó. Chapecó - SC - BR. E-mail: <golsson71@gmail.com>. https://orcid.org/0000-0003-2602-1320

** Mestranda em Direito pela Universidade Comunitária da Região de Chapecó. Bolsista CAPES/FAPESC. Chapecó - SC - BR. E-mail: <tuanalavall@unochapeco.edu.br>. https://orcid.org/0000-0001-8876-4299 
trabalho decente mediante a adoção de políticas públicas amplas, fortalecimento de pequenas empresas, apoio às iniciativas de economia solidária, reformas legislativas e potencialização da fiscalização do trabalho, tal êxito condiciona-se à atuação convergente de outros atores, mormente os que representam interesses econômicos, como as corporações transnacionais.

Palavras-chave: Trabalho decente. Desenvolvimento sustentável pluridimensional. Agenda 2030. Estado-nação.

\begin{abstract}
The United Nations (UN), in its latest global governance project, envisions the balanced performance of social, economic, environmental and political goals as the key to sustainable planetary development. Decent work, due to its emancipatory potential and affirming the human dignity, plays a strategic role in this process, deserving mention in the eighth Sustainable Development Goal (SDG). In this sense, this article verifies the limits and possibilities of the nation-state in performing decent work under the United Nations Agenda 2030, through bibliographic research, adopting the deductive method. The results show that while the nation-state can advance decent work through the adoption of broad public policies, the strengthening of small businesses, supporting solidarity economy initiatives, legislative reforms, and the enhancement of labor supervision, such success needs the convergent action of other actors, especially those representing economic interests, such as transnational corporations.
\end{abstract}

Keywords: Decent work. Multidimensional sustainable development. 2030 Agenda. Nation-State.

\title{
RESUMEN
}

La Organización de las Naciones Unidas (ONU), en su más reciente proyecto de gobierno global, vislumbra en la realización equilibrada de objetivos sociales, económicos, ambientales y políticos la clave para el desarrollo planetario en condiciones de sostenibilidad. El trabajo digno, por el potencial emancipatorio y afirmador de la dignidad humana que presenta, desempeña un papel estratégico en este proceso, mereciendo mención en el octavo Objetivo de Desarrollo Sostenible (ODS). En ese sentido, el presente artículo verifica cuáles son los límites y las posibilidades del Estado-nación en la efectivización del trabajo digno en el ámbito de la Agenda 2030 de las Naciones Unidas, a lo que procede por medio de pesquisa bibliográfica, adoptando el método deductivo. Los resultados indican que, aunque el Estado-nación pueda avanzar en la efectivización del trabajo digno mediante la adopción de políticas públicas amplias, fortalecimiento de las pequeñas empresas, apoyo a las iniciativas de economía solidaria, reformas legislativas y potencialización de la fiscalización del trabajo, tal éxito está condicionado a la actuación convergente de otros actores, principalmente los que representan intereses económicos, como las corporaciones transnacionales.

Palabas llave: Trabajo digno. Desarrollo sostenible pluridimensional. Agenda 2030. Estado-nación. 


\section{INTRODUÇÃO}

Os inúmeros desafios socioambientais, políticos e econômicos que se desenham na época contemporânea motivaram os países-membros da Organização das Nações Unidas (ONU) a assumir, em 2015, uma agenda norteadora dos esforços globais para o desenvolvimento sustentável. Seguramente, a realização desse ambicioso projeto, que persegue o equilíbrio planetário em benefício das presentes e futuras gerações, depende da atuação conjunta dos atores internacionais e, destacadamente, do Estado-nação.

Não se ignora, porém, que as transformações enfrentadas por esse tradicional ator - em virtude da globalização e da consequente reestruturação da ordem internacional - põem à prova o poder de governança por ele exercido, do que decorre a importância em analisar as suas potencialidades e fragilidades diante da nova e complexa agenda de desenvolvimento global. Mais especificamente, interessa saber qual é a influência do ente estatal na concretização do trabalho decente, objetivo de desenvolvimento sustentável elencado pela Agenda 2030 e, sobretudo, uma necessidade compartilhada por todos os indivíduos, por ser um meio de afirmação da dignidade humana.

Assim, partindo-se do referido panorama, o objetivo geral do presente artigo é verificar quais são os limites e as possibilidades do Estado-nação na efetivação do trabalho decente no âmbito da Agenda 2030 da ONU. Para o alcance desse intento, no que se refere aos procedimentos metodológicos, o estudo, que é de caráter qualitativo, utilizará o método dedutivo ${ }^{1}$, empregando a técnica de pesquisa bibliográfica, com consulta às literaturas brasileira e estrangeira - neste último caso, com traduções livres dos autores. Para tanto, o trabalho encontra-se estruturado em duas partes.

Inicialmente, abordam-se aspectos da construção da temática "trabalho decente" no âmbito da Organização Internacional do Trabalho (OIT) e do seu protagonismo na OIT, especialmente a partir da década de 1990. Buscam-se também subsídios doutrinários para uma definição contemporânea do termo, reconhecendo-se a limitação de qualquer tentativa conceitual estrita, uma vez que, por ser afeta à dignidade humana, a ideia do que seja um trabalho decente é permeada por imensa subjetividade. Ainda na primeira parte, situa-se a temática no marco da Agenda 2030 da ONU, enquanto se demarcam as transformações sucedidas nas relações laborais, ao longo das últimas décadas, e os óbices, criados por elas, à efetivação do trabalho dentro de padrões de decência.

Por fim, atenta-se para a investigação dos limites e das possibilidades do Estado-nação em promover o trabalho decente, em um contexto marcado pela fragmentação do poder, em que o ente estatal tem a sua soberania questionada continuamente. Dessa forma, expõem-se alguns desafios do Estado-nação nesse particular, ao passo que se sugestionam medidas, diretas

1 Radicado na filosofia racionalista, o método dedutivo vale-se do silogismo, ou seja, parte de duas premissas iniciais e pretende chegar a uma terceira por meio de construções lógicas (GIL, 2008, p. 9). Justifica-se a opção pelo raciocínio dedutivo, uma vez que é a análise dos contornos atuais do Estado-nação e da temática do desenvolvimento sustentável na Agenda 2030 que permitirá definir o papel do Estado-nação no que se refere à efetivação do trabalho decente. 
e indiretas, que ajudam a forjar o papel do aludido ator na afirmação do trabalho decente.

\section{O TRABALHO DECENTE ENQUANTO VETOR DE DESENVOLVIMEN- TO SUSTENTÁVEL}

Historicamente, a noção de desenvolvimento sustentável esteve associada à preservação ambiental, assumindo lugar de destaque na contraposição aos modelos de crescimento econômico irrestrito, praticados na segunda metade do século XX. Contudo, a partir da formação da Comissão Mundial sobre Meio Ambiente e Desenvolvimento, em 1983, e dos diversos eventos de cúpula realizados pela ONU na década de 1990, fortaleceu-se a ideia de que, para além da preocupação ecológica, um desenvolvimento que se pretende benéfico e estável ao longo do tempo precisa assegurar também sustentabilidade social e econômica por meio da boa governança.

Esse giro acadêmico-institucional permitiu que uma gama de novas questões pudesse ser vislumbrada sob a ótica do desenvolvimento sustentável e, assim, tornar-se foco da cooperação global, refletindo com mais coerência a complexidade e a interconectividade dos desafios contemporâneos. Afinal, em um mundo marcado por acentuadas transformações sociais, no qual a economia desempenha papel central, o colapso de alguma dessas esferas pode mostrar-se tão nefasto quanto o prenunciado para o meio ambiente natural.

Nesse sentido, o trabalho decente, ideal de um dos elementos fundadores da sociabilidade humana - o próprio trabalho -, é objeto de análise nesta primeira seção, na medida em que, com a agenda da ONU para o período 2015-2030, restou definitivamente consagrado como um dos vetores de desenvolvimento sustentável.

\subsection{APORTES PARA UMA DEFINIÇÃO DE TRABALHO DECENTE}

A categoria "trabalho", por si só e mesmo quando acompanhada do adjetivo "decente", dá margem para construções teóricas a partir de variadas matrizes, como a filosófica, a antropológica e a sociológica. É tarefa difícil, portanto, extrair um conceito "puro" de trabalho decente, porque é inevitável a correlação das muitas visões e perspectivas de seu sentido. Sem desconhecer dessa complexidade, incursiona-se, neste primeiro momento, pelas definições acerca da temática sob a ótica das organizações internacionais e da academia.

No plano internacional, o entrecruzamento inaugural entre os termos "decência" e "trabalho" deu-se com o Pacto Internacional de Direitos Econômicos, Sociais e Culturais, adotado pela Assembleia Geral da ONU, em 1966². O documento reconheceu o direito a condições

2 Nos trávaux préparatoires ao Pacto Internacional dos Direitos Econômicos, Sociais e Culturais, coordenados pela Comissão de Direitos Humanos da ONU, no âmbito da iniciativa que pretendia formular dois pactos - o outro viria a ser o de Direitos Civis e Políticos - para dar efetividade à Declaração Universal dos Direitos Humanos, a versão do artigo sobre as condições de trabalho foi redigida conjuntamente pelos representantes da França e dos Estados Unidos. Houve divergências entre os representantes dos dois países quanto à cláusula acerca da necessidade de o trabalho garantir uma vida decente para o trabalhador e sua família: enquanto Eleanor Roosevelt (Estados Unidos) votava pela sua exclusão do documento final, René Cassin (França) postulava a manutenção. Ao final, a posição do francês foi referendada pelos demais membros da Comissão (ECOSOC, 1951, p. 4-11). 
de trabalho justas e favoráveis, assecuratórias de uma existência decente para o trabalhador e sua família, previsão que, na sua incipiência, teve o grande mérito de caracterizar o trabalho, sobretudo enquanto meio para o alcance de uma vida digna.

Embora o Pacto Internacional dos Direitos Econômicos, Sociais e Culturais tenha representado algum avanço em termos conceituais, certamente não impediu a crescente exploração do trabalho humano, impulsionada em todo globo pelo modelo fordista, nos anos subsequentes à Segunda Guerra Mundial. Na década de 1980, enquanto o setor produtivo elegia a flexibilização das relações de trabalho como um dos meios para recuperar a competitividade e frear o crescente desemprego, a OIT era criticada por sua postura passiva diante dessa nova conjuntura de incertezas para os trabalhadores. Nessa quadra e para defender-se, a OIT protagonizou, nos anos 1990, importantes reações - pelo menos do ponto de vista formal - à precarização das condições de trabalho (MAEDA, 2017, p. 59).

Em 1998, a organização lançou a Declaração dos Princípios e Direitos Fundamentais no Trabalho, intentando assentar garantias mínimas aos trabalhadores em um contexto de crescente interdependência econômica. Elencando como preceitos básicos a liberdade de associação, a negociação coletiva, a eliminação do trabalho forçado, a abolição do trabalho infantil e a eliminação da discriminação em matéria de emprego e ocupação (OIT, 1998), a OIT “[...] passou de uma atitude reativa - visando, ao longo das décadas, desde a sua origem, a proteger os trabalhadores de práticas abusivas -, a uma postura proativa, buscando um ideal de trabalho nivelador das condições globais." (AZEVEDO NETO, 2015, p. 21).

Não obstante, para Standing (2008, p. 367), a Declaração não apresentava grandes novidades, uma vez que os quatro padrões por ela consagrados seriam “direitos negativos", questões de direito comum, prescindindo de agendas progressistas por parte do capital transnacional. Nas palavras do autor, "[é] mais fácil fazer Declarações sobre a necessidade de tratar homens e mulheres igualmente do que pedir a redistribuição de renda do capital para o trabalho." (STANDING, 2008, p. 369). Ou seja: o cerne da problemática da igualdade material, ou da própria questão da exploração entre classes, por exemplo, não fora atacado.

No ano seguinte ao da Declaração, por ocasião da 87a Conferência Internacional do Trabalho, o novo diretor-geral da OIT, Juan Somavía, anunciou a noção de trabalho decente como o "grande tema" do seu mandato. Na perspectiva traçada por Somavía, o trabalho decente representava o "[...] ponto de convergência de quatro objetivos estratégicos: a promoção dos direitos fundamentais no trabalho, o emprego, a proteção social e o diálogo social.” (OIT, 1999, online). O discurso do diretor-geral, transformado em relatório posteriormente, embora tenha anunciado objetivos para a consecução do trabalho decente, furtou-se de conceituar o termo.

Conforme assinala Maeda (2017, p. 62), a partir do ingresso formal do trabalho decente na pauta da OIT, os autores com publicação pela própria OIT passaram a usar indiscriminadamente a convergência das quatro estratégias como o conceito desse termo. Essa tendência é evidenciada, por exemplo, no posicionamento de Laís Abramo, ex-diretora da OIT no Brasil, para quem "[o] conceito de trabalho decente expressa a síntese do mandato histórico e dos 
objetivos estratégicos da Organização Internacional do Trabalho (OIT)”, quais sejam: “[...] a promoção das normas internacionais do trabalho, a geração de mais e melhores empregos para homens e mulheres, a extensão da proteção social e a promoção do tripartismo e do diálogo social.” (ABRAMO, 2010, p. 151).

Essa imprecisão conceitual, persistente até hoje, permite, na avaliação de Standing (2008, p. 370), que todos subscrevam à definição implícita de trabalho decente. Na asserção do autor, a forma como o termo tem sido invocado pelas lideranças da OIT reflete um forte desejo pela reafirmação da relevância da Organização na comunidade internacional, de modo que a utilização dessa ideia tem servido como conexão entre a OIT e os debates em voga dentro e fora da ONU, como aqueles sobre a pobreza, a globalização e o desenvolvimento.

A projeção alcançada por uma agenda que se debruça sobre o gênero trabalho, vale destacar, reforçou simbolicamente a presença, sob o manto protetivo mínimo fixado pela OIT, de um conjunto amplo de pessoas, e não apenas de empregados assalariados. No seu elenco, estão os trabalhadores à margem do mercado de trabalho estruturado, os trabalhadores subcontratados, terceirizados, autônomos ou por conta própria, os trabalhadores a domicílio e também todos os que realizam atividades na economia informal (ABRAMO, 2010, p. 152; PESSOA; SANTOS, 2017, p. 146).

A complexidade da narrativa que envolve a temática conduz Azevedo Neto (2015, p. 23) a afirmar que a dignidade da pessoa humana consiste no elemento nuclear da teoria do trabalho decente: "[...] desta irradiam os vetores justificadores da proteção do trabalho decente, do ponto de vista teórico e prático, em todas as suas formas, seja no emprego seja no trabalho autônomo." (AZEVEDO NETO, 2015, p. 50-51).

Em "A condição humana”, Arendt (2007, p. 15) aproxima os temas do trabalho e da dignidade. De acordo com a autora, os homens dedicam-se a três atividades fundamentais:

a) o labor, atividade do animal laborans para a garantia da própria sobrevivência, que não deixa marcas duráveis no mundo por desaparecer com o consumo;

b) o trabalho (ou obra), atividade pela qual o homo faber "produz o mundo artificial das coisas”, isto é, os objetos que não se destinam unicamente à manutenção da vida biológica e;

c) a ação, atividade que, diferentemente das outras duas, implica a interação direta entre os homens, constituindo, pois, a espinha dorsal da vida política (ARENDT, 2007, p. 15-16).

Na sociedade moderna, dominada pelo consumo, a atividade do animal laborans, destituída de valor social, reificada, sufraga a do homo faber, deteriorando a própria dignidade dos homens. Nas palavras de Arendt (2007, p. 334), “[o] último estágio de uma sociedade de operários, que é a sociedade de detentores de empregos, requer de seus membros um funcionamento puramente automático”, como se "[...] a única decisão ativa exigida do indivíduo fosse deixar-se levar, por assim dizer, abandonar a sua individualidade, as dores e as penas de viver ainda sentidas individualmente, e aquiescer num tipo funcional de conduta entorpecida 
e tranqüilizada" (ARENDT, 2007, p. 334). O diagnóstico da autora é importante porque evidencia que o mesmo trabalho que afirma a dignidade humana pode, em outro estágio - isto é, o estágio da "vitória do animal laborans" -, esvaziá-la.

Para Rodgers (2002, p. 13), o trabalho decente implica mais do que a mera realização de uma atividade em condições adequadas. É sobre as perspectivas de futuro cultivadas pelo trabalhador, o equilíbrio da vida laboral e familiar, a igualdade de gênero, a possibilidade de poder expressar-se e de ser escutado no ambiente de trabalho e na comunidade. Enquanto, para muitos, significa um caminho para fugir da pobreza, para uma parcela mais abastada reveste a possibilidade de realização dos designíos pessoais. Por causa dessa carga de subjetividade que envolve a categoria, o autor conclui ser o trabalho decente, sobretudo, uma questão de dignidade humana (RODGERS, 2002, p. 14).

Não obstante existir uma dimensão positiva do trabalho decente, anunciadora de todos os elementos que o promovem, não se pode negar que a decência do labor está condicionada à eliminação dos seus aspectos negadores. Com fundo nessa antítese negativo/positivo, Azevedo Neto (2015) assevera que a dimensão negativa do trabalho decente é composta de:

a) eliminação do trabalho forçado;

b) erradicação do trabalho infantil;

c) fim da discriminação no meio laboral e;

d) ausência de impedimentos à participação sindical e à negociação coletiva. Por outro lado, retirados os entraves, a dimensão positiva é constituída por:

e) liberdade de escolha do trabalho;

f) igualdade de oportunidades;

g) saúde e segurança;

h) remuneração justa;

i) licitude da atividade desenvolvida e;

j) lazer e aposentadoria digna (AZEVEDO NETO, 2015, p. 60-65).

Apesar da justeza com que se preenche teoricamente a noção de trabalho decente, é improvável que exista, na prática, um labor que corresponda integralmente a esse ideal de decência, mesmo nos países desenvolvidos. Desse modo, prefere-se "[...] encarar a questão sob o ponto de vista da busca por um trabalho mais decente, livre de qualquer mácula ou imperfeição", defendendo-se uma "[...] aproximação dos princípios expostos ao máximo, mas sem deixar de reconhecer que o preenchimento de mais requisitos, ainda que não todos, torna o trabalho mais decente e a ausência de muitos resulta num trabalho menos decente." (AZEVEDO NETO, 2015, p. 119).

Em outras palavras,

[é] necessário que o trabalho decente tenha um piso básico e mínimo que diga respeito a direitos e princípios universais, mas não um teto. $\mathrm{O}$ que se considera trabalho decente acima desse limite mínimo reflete os valores e possibilidades de cada sociedade em cada momento histórico (ABRAMO, 2010, p. 153). 
Na prática mais recente da OIT, a temática do trabalho decente foi abordada em Resolução sobre as cadeias globais de produção, datada de junho de 2016, na qual se reconhece que o modo de operação de muitas cadeias globais, especialmente dos seus segmentos mais inferiores, fere o trabalho decente por apoiar-se em práticas como a exploração do trabalho infantil e do trabalho dos migrantes, as jornadas laborais excessivas, a discriminação das mulheres, entre outras. Para enfrentar esses desafios, a Resolução sugere medidas de governança a serem adotadas pela iniciativa privada, pela OIT, pelos governos e seus parceiros sociais, para garantir a simetria entre os resultados econômicos e o trabalho decente nas cadeias globais de produção. Vale mencionar que, nesse âmbito, delineia um ambicioso plano de ação para a OIT, com estratégias que variam desde o fornecimento de assistência técnica aos Estados-membros até a atuação ativa na geração e na disponibilização de dados sobre as condições de trabalho nos Estados-membros (ILO, 2016, p. 1-5).

Os países do G20, por outro lado, formalizaram o seu compromisso com a promoção do trabalho decente na Declaração "Inovação e crescimento inclusivo: trabalho decente, empregabilidade aprimorada e oportunidades de emprego adequadas”, fruto da reunião dos ministros do Trabalho e Emprego do Grupo, realizada em Pequim, em julho de 2016 (G20, 2016, p. 4).

Assim, guardada a generalidade das considerações conceituais até aqui articuladas, pode-se afirmar que o trabalho decente tem, por assim dizer, a sua própria agenda, planeada desde os últimos anos da década de 1990 pela OIT e reafirmada por outros organismos e fóruns internacionais, e que, agora, foi trazida para o interior do projeto pós-2015. Além disso, como se verá adiante, mesmo que o Objetivo de Desenvolvimento Sustentável 8 não discrimine todos os elementos conformadores do trabalho decente, o simples emprego do termo eleva-os, implicitamente, à condição de fins perscrutáveis.

\subsection{O TRABALHO DECENTE NA AGENDA 2030 DA ONU E OS DESAFIOS CONTEM- PORÂNEOS DO MUNDO DO TRABALHO}

O recorte da presente pesquisa exige um olhar especial à disciplina do trabalho decente na Agenda 2030 da ONU para, posteriormente, confrontá-lo com o atual panorama do mundo do trabalho. Antes, contudo, importa apresentar brevemente o projeto pós-2015 que inaugura um novo referencial civilizatório.

Em 2012, o Rio de Janeiro sediou a Conferência das Nações Unidas para o Desenvolvimento Sustentável, cuja realização se deu, coincidentemente, no momento em que a ONU começava a preparar uma nova agenda de desenvolvimento (BROWNE, 2017, p. 92). Não por acaso, o documento final da Rio+20 reconheceu a importância e a utilidade de se criar um quadro de objetivos de desenvolvimento sustentável que contemplasse "[...] de forma equilibrada as três dimensões do desenvolvimento sustentável e suas interligações." (ONU, 2012, p. 49).

Com esse fito, os 193 países-membros da ONU trabalharam, entre 2012 e 2015, na elaboração de 17 Objetivos de Desenvolvimento Sustentável (ODS) e 169 metas, adotados 
formalmente no dia 25 de setembro de 2015, na Conferência das Nações Unidas para o Desenvolvimento Sustentável, em Nova Iorque (SACHS, 2017, p. 485).

A nova proposta, sob o título "Transformando Nosso Mundo: A Agenda 2030 para o Desenvolvimento Sustentável”, apresenta, logo em seu preâmbulo, a indicação de que os objetivos e as metas ali traçados se alicerçam nos Objetivos de Desenvolvimento do Milênio, datados de 2000, no afã de alcançar o que não foi por eles efetivado. Nessa senda, a "[...] erradicação da pobreza em todas as suas formas e dimensões" assenta-se como o desafio global mais elevado e pressuposto básico para o desenvolvimento sustentável (ONU, 2015, p. 1).

O trabalho decente é mencionado expressamente na Agenda 2030, constituindo parte do oitavo Objetivo de Desenvolvimento Sustentável: "Promover o crescimento econômico sustentado, inclusivo e sustentável, emprego pleno e produtivo e trabalho decente para todos." (ONU, 2015, p. 26, grifo nosso).

A aproximação entre os temas do trabalho decente e do crescimento econômico não parece ser fruto do acaso; ao passo que se admite a necessidade de crescimento - um crescimento qualificado, diga-se de passagem -, o trabalho decente aparece enquanto limitador desse processo, no sentido de que o progresso é desejável, mas não a qualquer custo. Devem ser respeitadas, em primeiro lugar, as pessoas, que, não é demais lembrar, são definidas como uma das prioridades da Agenda.

Dito isso, importa mencionar que, consoante a sistemática adotada pelo projeto pós2015, o Objetivo 8 vem acompanhado de 10 metas, entre as quais a 8.5, a 8.6, a 8.7 e a 8.8 apresentam relação mais íntima com o tema do trabalho decente, motivo pelo qual serão analisadas de forma detalhada a seguir.

Diz a meta 8.5: "Até 2030, alcançar o emprego pleno e produtivo e trabalho decente para todas as mulheres e homens, inclusive para os jovens e as pessoas com deficiência, e remuneração igual para o trabalho de igual valor.” (ONU, 2015, p. 27). Além de reforçar ideias presentes no texto do próprio objetivo - "emprego pleno e produtivo e trabalho decente para todos" -, a meta em comento traz a lume o princípio da igualdade de oportunidades e não discriminação, mandamento que, como já visto, há muito é enunciado nos instrumentos da OIT como requisito para o trabalho decente.

O princípio da igualdade e não discriminação confere a todos os seres humanos, independentemente de raça, crença ou sexo, o direito de efetuar "[...] o seu progresso material e o seu desenvolvimento espiritual em liberdade e com dignidade, com segurança econômica e com oportunidades iguais” (OIT, 1944, online). Essa emblemática previsão da Declaração de Filadélfia esbarra, contudo, em uma realidade na qual, apesar dos progressos modestos verificados em determinadas regiões do globo, as mulheres, os jovens e as pessoas pertencentes a grupos vulneráveis ainda enfrentam grandes desafios para encontrar e manter trabalhos decentes.

Apenas para exemplificar, em relatório da OIT de 2016, apurou-se que os avanços empreendidos pelas mulheres, em termos de educação, ao longo das últimas décadas, não se traduziram em melhorias comparáveis nas suas posições de trabalho. No que concerne ao salário, o relatório aponta 
que, globalmente, as mulheres ainda ganham, em média, 77\% do total percebido pelos homens (ILO, 2016, p. 16). Na mesma linha, a busca por emprego pleno e trabalho decente, especialmente para os jovens, mencionada na meta 8.5 e retomada na meta 8.6 - "Até 2020, reduzir substancialmente a proporção de jovens sem emprego, educação e formação” -, revela a justa preocupação com um quadro social no qual as pessoas dessa faixa etária têm propensão três vezes maior que os adultos a estar desempregadas (UNDP, 2016, p. 34). Certamente, tais casos, utilizados para ilustrar a discriminação na esfera do trabalho, não esgotam a infinidade de situações assemelhadas que poderiam ser traduzidas em dados estatísticos - e aqui apresentadas.

A meta 8.7, por sua vez, prevê a necessidade de "[...] erradicar o trabalho forçado, acabar com a escravidão moderna e o tráfico de pessoas, e assegurar a proibição e eliminação das piores formas de trabalho infantil, incluindo o recrutamento de crianças-soldado, e até 2025 acabar com trabalho infantil em todas as suas formas”. Está contemplado, nesse ponto, o que Azevedo Neto (2015, p. 6-65) denominou dimensão negativa do trabalho decente, isto é, o conjunto elementos cuja não eliminação compromete a decência do trabalho.

Atualmente, trabalho forçado, escravidão moderna e tráfico humano são termos que se relacionam, ainda que não haja total correspondência entre eles. Tanto a escravidão moderna quanto o tráfico humano podem ser entendidos como formas de trabalho forçado, implicando, na primeira, o domínio absoluto de uma pessoa por outra e, no segundo, o recrutamento, o transporte e o acolhimento de pessoas, com o uso da força ou outros meios de coação, para fins de exploração (ILO, 2012).

No universo de 24,9 milhões de ocorrências de trabalho forçado registradas no ano de 2016, pelo menos 16 milhões resultaram de imposições de agentes privados. A maioria dessas vítimas trabalhava em atividades como agricultura, pesca, construção civil, confecção têxtil, mineração, serviços e trabalho doméstico (ILO, 2017b, p. 11). Acredita-se ainda que as formas modernas de trabalho forçado estejam associadas à globalização e às recentes tendências migratórias e sejam arquitetadas por uma gama de atores - como o crime organizado e o terrorismo - em busca de vantagens financeiras ilícitas. Nesse cenário, o trabalho forçado revela-se notadamente por meio de restrições à liberdade de ir e vir, da retenção de documentos de identidade e das ameaças de denúncia às autoridades de imigração contra os migrantes que se queixam de condições de vida e de trabalho abaixo das mínimas (OIT, 2005, p. 9-10).

Outra problemática levantada pela meta 8.7 é a do trabalho infantil, definido como aquele realizado por crianças com idade abaixo da mínima permitida para o labor ou cuja condição de sua realização seja prejudicial à sua segurança ou à sua saúde, física e moral. Em estudo referente ao ano de 2016, revelou-se que o setor agrícola responde por $71 \%$ dos casos de trabalho infantil, ou seja, um total de 108 milhões de crianças, em termos absolutos. $O$ número de crianças laborando na área de serviços e na indústria perfaz 26 milhões (17,2\%) e 18 milhões (11,9\%), respectivamente, embora esses setores tendam, no futuro, a concentrar mais casos, em decorrência das mudanças climáticas que obrigam muitas famílias a deslocarem-se do campo para a cidade (ILO, 2017a, p. 34). 
Em continuidade, avança-se para a meta 8.8, de seguinte teor: "Proteger os direitos trabalhistas e promover ambientes de trabalho seguros e protegidos para todos os trabalhadores, incluindo os trabalhadores migrantes, em particular as mulheres migrantes, e pessoas em emprego precário." (ONU, 2015, p. 27). As questões abordadas por essa meta, especialmente no que concerne à proteção dos direitos trabalhistas, são mais hodiernas, refletindo as necessidades de grandes massas de trabalhadores que, desde a substituição do modelo de produção fordista pelo da acumulação flexível, verificada entre os anos 1970 e 1980, vivenciam mudanças acentuadas, e nem sempre positivas, nas relações de trabalho.

Tendo a demanda do mercado como orientadora da produção, a reestruturação produtiva e o novo modo de acumular capitais, assomados ao fenômeno globalizante, introduziram a lógica da flexibilidade no trabalho, provocando, nesse terreno, transformações severas (ANTUNES, 2010, p. 182-183). Entre as questões que desencadearam sérias consequências para trabalhadores e governos de todas as partes do mundo, embora com mais impacto entre os países emergentes e subdesenvolvidos, ressalta-se a redução dos postos de trabalho e o surgimento de novas e precárias relações de trabalho (LAZZARESCHI, 2018, p. 94-95; ANTUNES, 2010, p. 103).

Objetivando diminuir os custos de produção, as empresas passaram a empregar tecnologias sofisticadas, que permitiram reduzir drasticamente os níveis de contratação de novos trabalhadores, enquanto se intensificou o trabalho daqueles ainda necessários (LAZZARESCHI, 2018, p. 94-95). Nas palavras de Albuquerque (2006, p. 51), a mão de obra excedente, fruto do "desemprego tecnológico", não foi reabsorvida porque, além de serem ofertados em menor número, os novos empregos exigiam uma qualificação maior.

Com efeito, ainda hoje, o discurso da flexibilidade obstaculiza a melhoria da condição social do trabalhador e o trabalho decente, porque, "[...] para corresponderem à necessidade individual dos consumidores, à demanda variável e à ausência de estoques, os contratos de trabalho devem ser flexíveis; os horários de trabalho, idem; e, se possível, os trabalhadores também.” (MAEDA, 2017, p. 45). Interessante notar, contudo, que o traço mais característico do sistema, o paradoxo produção social versus apropriação individual, mantém-se "rígido" no binômio da concentração de renda e da centralização do capital.

O trabalho contratado e regulamentado, dominante no século XX, tornou-se informalizado, quando não substituído pelas diversas formas de empreendedorismo, cooperativismo, trabalho voluntário, trabalho atípico etc. (ANTUNES, 2010, p. 108). No recorte específico do Brasil, esse quadro está bem desenhado: segundo dados do Instituto Brasileiro de Geografia e Estatística (IBGE), divulgados pelo portal Valor Econômico, o país encerrou o ano de 2017 com um número maior de pessoas que trabalham por conta própria ou em vagas sem carteira assinada (34,31 milhões de pessoas) do que de empregados formais (33,32 milhões de pessoas) (VILLAS BÔAS, 2018).

Preocupa, portanto, o fato de muitas das novas configurações de labor não mais oferecer as garantias sociais e trabalhistas conquistadas desde o início da Revolução Industrial e con- 
clamadas na meta 8.8 da Agenda. Esse processo de supressão das barreiras, outrora levantadas pela luta de classe em resistência à voracidade do capitalismo, é chamado de precarização, fenômeno que funciona como um modo de "reposição socio-histórica" do pior tipo de precariedade social existente, a precariedade do trabalho, condição pela qual a força de trabalho humano é percebida, continuamente, como mera mercadoria (ALVES, 2007, p. 112-114).

Para Maeda (2017, p. 46), a precarização do trabalho desdobra-se em duas vertentes: a precarização do emprego e a precarização das condições de trabalho. No âmbito da primeira, sublinha-se o tendencial afastamento do trabalhador do seu real empregador por conta das contratações atípicas, notadamente das terceirizações; em contrapartida, consideram-se precarizadas as condições de trabalho em razão da retirada de direitos sociais e da ampliação das horas destinadas ao trabalho, com a consequente diminuição do tempo livre, ou "[...] redução do tempo de vida a tempo de trabalho." (ALVES, 2007, p. 237).

O trabalho flexível, ao desmontar formas contratuais seguras, altera os modos usuais de remuneração e da organização da jornada laboral, implicando também, e em última análise, a precarização do trabalhador enquanto sujeito capaz de reagir ao movimento do capital. De acordo com Alves (2013, p. 177), "[...] a nova morfologia social do trabalho flexível tem um impacto disruptivo no metabolismo social do homem-que-trabalha, atingindo irremediavelmente a vida cotidiana de homens e mulheres trabalhadores, disseminando sentimentos de insegurança e descontrole pessoal.” Destarte, não é preciso muito esforço para perceber que um trabalho causador da desordem íntima do trabalhador está longe de ser considerado decente.

Em tempos de flexibilização do trabalho, as estratégias de gestão fundamentadas na quebra da autoestima como pessoa humana e na administração pelo medo tornam o trabalhador um carrasco de si mesmo. Por exemplo, a estipulação de planos de metas o conduz a situações de autocobrança excessiva, que resultam em danos graves à dimensão física da "[...] corporalidade da força de trabalho" e ao aspecto psíquico, com recorrentes manifestações de doenças psicossomáticas, sendo o estresse a mais comum (ALVES, 2007, p. 235-236).

Sem embargo, importa salientar que essa captura da subjetividade humana ultrapassa o universo dos trabalhadores empregados, tratando-se de um processo amplo de subsunção do trabalho ao capital, em que a identidade do homem se molda ao gosto do sistema. Nesse quadro, o trabalhador por conta própria, por exemplo, é, a rigor, assalariado porque está subsumido ao capital, não formalmente, mas no sentido ideal: "[...] ele possui um patrão, é patrão de si mesmo, o patrão está dentro de si” (ALVES, 2011, p. 20), obrigando-o a exaurir ao máximo sua capacidade de trabalho para poder inserir-se na sociedade do consumo.

Além do tensionamento no campo subjetivo, o atual panorama do trabalho é marcado por uma crise da sociabilidade. Diante da deterioração das interações travadas entre os trabalhadores, as práticas coletivistas e os ideais de solidariedade, que, durante o século XX, sustentaram as atividades sindicais, encontram-se, hoje, em franca desintegração. A cultura vigente prima, antes de qualquer proveito coletivo, pelo bem-estar individual, pela projeção da imagem e pelos valores do sucesso e do dinheiro (ALVES, 2011, p. 11-13). 
Nesse sentido, e a partir da breve contextualização traçada na presente seção, sem a qual, certamente, o estudo ficaria distanciado da realidade, pode-se concluir que não são poucos, e nem de uma única ordem, os óbices colocados à efetivação do trabalho decente. É, porém, desse confronto entre o desejável e o existente que se adquire maior aptidão para conduzir esta pesquisa à sua parte final, na qual será explorado em que medida o Estado-nação está engajado com o novo paradigma do desenvolvimento pluridimensional, anunciado na Agenda 2030, e, especificamente, o que ele pode ou não realizar no âmbito do objetivo de trabalho decente.

\section{O PAPEL DO ESTADO-NAÇÃO NA AFIRMAÇÃO DO TRABALHO DE- CENTE}

A Agenda 2030 da ONU desafia a espécie humana a mudar radicalmente os seus hábitos de consumo e produção, a forma como interage entre si e com o meio ambiente natural. Embora o documento reúna objetivos potencialmente unificadores, há uma clara preocupação em assegurar a cada Estado que o afiançou a liberdade de, a partir desse ponto de partida, traçar os próprios projetos de desenvolvimento, condizentes com as necessidades e as realidades nacionais e, consequentemente, regionais e locais.

Afinal, em um mundo acelerado, dividido, superpopuloso e sobrecarregado de informações, a identificação de objetivos, anota Sachs (2017, p. 490), permite direcionar a ação social e pressionar os líderes políticos diante de seus pares, uma vez que o progresso no cumprimento dos objetivos, ou a falta dele, será relatado, comparado e cobrado internacionalmente. Outra vantagem da adoção de uma agenda é a mobilização por ela provocada nas comunidades epistêmicas que passam a mover-se em torno de desafios específicos.

Em um passado não muito distante, experiências semelhantes de governança global por meio de metas alcançaram algum êxito. Assumidos em 2000, os Objetivos de Desenvolvimento do Milênio, centrados na diminuição da pobreza e da fome, apresentaram bons resultados na América Latina e no Caribe, por exemplo, onde se reduziu pela metade a taxa de pobreza extrema, com a proporção de pessoas vivendo com menos de 1,25 dólar por dia caindo de 13\%, em 1990, para 4\%, em 2015 (UNITED NATIONS, 2015, p. 15).

Evidências como essa acalentam a esperança de uma promissora transição para o desenvolvimento sustentável pluridimensional por meio da Agenda 2030. No tocante às relações laborais especificamente, ainda que uma leitura marxista mais ortodoxa tenda a considerar indigna toda forma de trabalho subordinado, em uma visão mais moderada, como a entabulada pela OIT, é salutar que existam ao menos limites ao nível de exploração do trabalho para que se possa falar na decência insculpida no Objetivo 8 .

A declaração que a Agenda 2030 profere, no entanto, é formal, e, por mais que tenham sido desenhadas metas para a consecução do trabalho decente, a materialização do objetivo está à mercê do comportamento dos diferentes agentes que têm poder para influenciar o universo do trabalho. Chega-se, portanto, ao ponto-chave do presente estudo: como não relegar a Agenda 2030 à inefetividade? Ou melhor, diante de um cenário de policentricidade, quais 
são os limites e as possibilidades do Estado-nação, ator sensivelmente afetado pelo fenômeno globalizante em curso, na promoção do trabalho decente?

Introduzindo a noção de governança policêntrica, Prenkert e Shackelford (2014, p. 459) afirmam que o Estado deixou de ser a única fonte de autoridade na sociedade contemporânea. Constata-se a existência de um "[...] complexo conjunto de entidades interdependentes ou centros de tomada de decisão, estatais e não estatais, que podem ser formalmente independentes um do outro, formando redes e interagindo entre si." (PRENKERT; SHACKELFORD, 2014, p. 459). Considerada na sua individualidade, cada uma dessas entidades tem algum "valor" para oferecer, de modo que, no conjunto, as limitações uma das outras são compensadas. Elas são também livres e autônomas, podendo instituir regramento próprio dentro de seu domínio de influência (PRENKERT; SHACKELFORD, 2014, p. 460).

A governança policêntrica emerge quando, diante de um problema que requer a ação coletiva, o Estado mostra-se mal equipado, desinteressado ou vagaroso em resolvê-lo por si próprio (PRENKERT; SHACKELFORD, 2014, p. 460). Como pontua Castells (2008, p. 83), diminuída a capacidade dos governos em mitigar as crises, "[...] os atores não-estatais tornam-se os defensores das necessidades, interesses e valores das pessoas em geral, minando ainda mais o papel dos governos em resposta aos desafios colocados pela globalização e transformação estrutural." Entre esses atores, o autor destaca as organizações não governamentais, os movimentos sociais globais e os movimentos da opinião pública, reconhecendo o seu papel na conformação de uma "sociedade civil global" (CASTELLS, 2008, p. 84-86).

No Relatório "Nós, os Povos: Sociedade Civil, Nações Unidas e Governança Global”, fruto do Painel de Pessoas Eminentes sobre as Nações Unidas - Relações com a Sociedade Civil, de 2004, a ONU reconhece que poucos dos desafios da atualidade podem ser resolvidos apenas pelos governos. Agentes da sociedade civil organizada, do setor privado, além das autoridades locais, pelos conhecimentos e pelas habilidades que detêm, devem merecer maior protagonismo na condução de questões de interesse global, como a mudança climática e o terrorismo. Caberia à própria ONU, de acordo com o documento, "[...] enfatizar a inclusão de todos os grupos constituintes relevantes para uma temática, reconhecer que os atores são diferentes para diferentes questões e promover parcerias de várias partes interessadas para criar soluções pioneiras" (UNITED NATIONS, 2004, p. 31), no que se convencionou denominar multi-stakeholderism³.

Em outra perspectiva, embora reconheça que a governança não se reduz a ações governamentais e que o desenvolvimento sustentável envolve processos de autodireção social, Meadowcroft (2007, p. 116) tributa aos governos nacionais grande parte da responsabilidade em garantir o ingresso em uma trajetória sustentável. Os governos, explica o autor, são as únicas instituições com um mandato geral para promover, em tese, o bem público, existindo

3 Para Benedek (2011, p. 210), o multi-stakeholderism é uma nova forma de multilateralismo, que, embora não substitua estruturas multilaterais tradicionais, fundamentadas em convenções, complementa-as, fornecendo novas bases para pensar as preocupações públicas internacionais, cujo foco "[...] reside em garantir estruturas de governança mais inclusivas". O autor destaca a importância do multi-stakeholderism em pelo menos quatro campos do Direito Internacional: a governança da internet, o desenvolvimento sustentável, os direitos humanos e a segurança. 
linhas claras de responsabilidade perante a população, e, se o desenvolvimento sustentável requer um elemento interativo e participativo, também demanda estruturas formais capazes de fazer escolhas políticas confiáveis.

Dessa forma, os "Estados representam tanto um meio para moldar a 'sociedade' como um quadro através do qual a 'sociedade' pode influenciar a orientação dessa modelagem” (MEADOWCROFT, 2007, p. 111), consagrando-se a importância de um ambiente democrático para a busca do desenvolvimento sustentável, porque apenas ele impede que governos com compreensões inadequadas da realidade natural e social tenham o poder incontestável de impor seus projetos à sociedade.

O papel do Estado na promoção do trabalho decente, em um quadro de desenvolvimento sustentável, pode ser exercido a partir de frentes diversas: por meio do desenvolvimento de políticas públicas, sejam elas específicas às questões laborais, sejam elas atinentes à seara ambiental e socioeconômica amplamente consideradas (distribuição de renda, combate à fome, qualificação profissional etc.), mas cujos reflexos serão sentidos também no âmbito do trabalho, tendo em vista a interconectividade que o desenvolvimento sustentável pluridimensional propõe; pelo adequado exercício do poder legiferante, alinhado à meta 8.8 da Agenda, objetando-se retrocessos ou perda de direitos, ao passo que se modernizam as legislações para abarcar, sob o manto protetivo do Direito do Trabalho, a nova gama de trabalhadores (informais, teletrabalhadores, migrantes etc.) e os novos direitos decorrentes das relações de trabalho contemporâneas (regulação do uso de tecnologias e sistemas de inteligência artificial na esfera do trabalho, por exemplo); pela potencialização ou reestruturação dos mecanismos de fiscalização capitaneados pelo Estado, medida que pode ser uma grande aliada no combate ao trabalho forçado, escravidão moderna, tráfico de pessoas e trabalho infantil, como quer a meta 8.7.

Essas alternativas, enumeradas exemplificativamente e que serão retomadas adiante, referem-se, em suma, ao que o Estado pode fazer do ponto de vista interno, e a elas devem ser somadas as articulações, em prol do trabalho decente, travadas na ordem internacional - ratificação das convenções e dos protocolos e observância às recomendações da OIT, cooperação internacional para agenda do trabalho decente, assistência e financiamento público aos Estados cujos recursos são limitados, entre outras medidas.

Ao que parece, o grande desafio do Estado é traduzir em ações concretas os compromissos assumidos nas normas de direito internacional e de soft law, sem quedar diante da influência do poder econômico. Nessa perspectiva, instrumentos como os Princípios Orientadores sobre Empresas e Direitos Humanos das Nações Unidas, ou simplesmente Princípios Ruggie 4 ,

4 Formulado por John Ruggie, professor da Universidade de Harvard, o conjunto de Princípios foi concebido para assegurar que as empresas não violem os direitos humanos no curso de suas operações ou forneçam reparação, em caso de violação. Os dez primeiros Princípios, direcionados ao Estado, apresentam orientações sobre como esse ator deve atuar na promoção dos direitos humanos por parte das empresas. Na sequência, aparecem 14 Princípios voltados para as empresas, tanto transnacionais como de outro tipo. Uma terceira seção do documento contém Princípios de "Acesso à reparação", que dispõem sobre a responsabilização dos agentes e reparação às vítimas, quando da violação de direitos humanos pelas empresas (HUMAN RIGHTS COUNCIL, 2011). 
e a Declaração Tripartite de Princípios sobre Empresas Multinacionais e Política Social5, da OIT, são importantes mecanismos de regulação da conduta de agentes econômicos transnacionais, que podem contribuir não só para o ODS 8, mas também viabilizar o envolvimento do setor privado na "parceria global revitalizada" para a realização da Agenda 2030, como quer o ODS 17.

Traçando um panorama sobre os limites da atuação do Estado em diferentes instâncias de poder, já se atentou que, em nível local, a capacidade de cidades ou províncias estabelecerem políticas efetivas de trabalho decente é bastante deficiente. Primeiro, porque a regulamentação normativa das relações de trabalho se dá, normalmente, em nível nacional - a Constituição do Brasil, ao reservar à União a competência para legislar sobre a matéria trabalhista, exemplifica esse quadro -, restando, assim, pouca margem para regramentos complementares. Segundo, porque a regulação local ou regional mais benéfica ao trabalho tende a afugentar o capital para outros locais ou regiões, nos quais as condições para auferir lucro sejam mais favoráveis (OLSSON, 2002, p. 85-86).

Basta pensar no impacto causado pela expansão das redes globais de produção na estrutura de políticas de nível nacional: predominam políticas que encorajam reformas para liberar restrições ou regulamentações sobre as forças de mercado e para reduzir o papel do Estado nas áreas econômicas (POSTHUMA, 2010, p. 58-59). Assiste-se, pois, ao sintomático enfraquecimento das políticas de bem-estar social e de intervenção estatal no domínio econômico, e, por consequência, a capacidade estatal para projetar, materializar e gerir políticas de trabalho jamais esteve tão limitada.

Com extraordinária velocidade de deslocamento de capital, direcionando-os ora a um Estado, ora a outro, as empresas transnacionais, raramente preocupadas com as necessidades nacionais, obstaculizam a efetivação das escassas políticas públicas existentes. A partir de um modo de operação particular, quando seus interesses não são atendidos em um Estado, tais potências deslocam-se para outro, exigindo condições melhores na perspectiva do seu proveito econômico.

O deslocamento da empresa provoca, obviamente, mudanças em postos de trabalho e em investimentos. $O$ Estado encontra-se, então, em um impasse diante das poderosas empresas transnacionais: "[...] de um lado, recus[á-las] implica perder as oportunidades em proveito do Estado vizinho, e, de outro lado, aceit[á-las] implica cair na armadilha da racionalidade econômica com a renúncia do interesse público em termos sociais, tributários ou mesmo ambientais." (OLSSON, 2014, p. 22).

O jogo do capital mina a eficácia dos direitos sociais, porque as empresas não vislumbram grandes riscos de punição caso venham a descumprir as normas tutelares, e, mesmo que

5 Publicada originalmente em 1977 e revisada em 2017 para incorporar as diretrizes da Agenda 2030, a Declaração é o único documento sobre responsabilidade social corporativa e práticas sustentáveis no âmbito das empresas elaborado e adotado de forma tripartite por governos, organizações de empregadores e de trabalhadores. Os princípios estipulados no instrumento oferecem, às empresas, aos governos, a empregadores e trabalhadores, orientações em matéria de emprego, formação, condições de trabalho e de vida e de relações de trabalho (ILO, 2017). 
advenham penalidades, além de serem baixos os custos de reparação, com frequência eles são superados pelo decurso do tempo até alcançarem a exigibilidade. Por outro lado, a concorrência na produção global acaba por pressionar as empresas locais, que, para diminuírem os custos de produção, passam a usar mão de obra flexível, envolvendo formas de trabalho não cobertas ou omitidas pelos mecanismos legais e reguladores (POSTHUMA, 2010, p. 59).

Apesar dessas limitações impostas direta ou indiretamente pelo mercado, o Estado, dentro das possibilidades que lhe restam, deve atuar proativamente na construção de políticas econômicas (e não apenas de trabalho e renda), visando à minimização do impacto das estratégias das transnacionais sobre sua realidade nacional. Acalentar uma ruptura completa com o modo de produção capitalista parece uma alternativa irrealista; seria mais praticável, sim, a adoção de medidas que se aproximassem ao sistema de valores básicos, como a solidariedade, a exemplo da regulação sociojurídica eficiente dos principais agentes econômicos (OLSSON, 2002, p. 92; OLSSON, 2014, p. 29).

Tem-se por certo, entretanto, que a governança com governo para o desenvolvimento sustentável e, particularmente, para o trabalho decente perpassa pela realização de escolhas. Na sociedade contemporânea, complexa e globalmente interligada, os governos são obrigados a enfrentar objetivos múltiplos, conflitantes e, por vezes, incompatíveis, e nem sempre dispõem de conhecimento suficiente sobre as questões que causam preocupação e que devem ser objeto de políticas públicas (MEADOWCROFT, 2007, p. 113).

Para Fields (2003, p. 247), mesmo que o trabalho decente fosse proclamado como principal objetivo de um Estado, ainda assim os governantes teriam que decidir como mover-se entre a promoção da quantidade (criação de postos de trabalho) e da qualidade (melhoria das condições laborais) do trabalho. $\mathrm{O}$ autor denomina benéfica a ação política que consegue equilibrar esses componentes, e, segundo ele, o caminho, para tanto, é tratar as políticas econômicas e as políticas sociais "[...] como parte integrante de uma mesma coisa" (FIELDS, 2003, p. 247).

Nessa trilha, as ditas políticas para o trabalho decente seriam indissociavelmente econômicas e sociais, concentrando-se em três conjuntos principais: 1) as políticas de demanda por mão de obra, perpassando pelo fortalecimento da indústria e do comércio dadas suas potencialidades para a criação de novos postos de trabalho; 2) as políticas de oferta de trabalho, voltadas para a qualificação do capital humano disponível para o trabalho, por meio de políticas de educação, treinamento e outros tipos de desenvolvimento de habilidades; e 3) as políticas de funcionamento do mercado de trabalho, compreendendo políticas de proteção social e salarial (FIELDS, 2003, p. 250).

Com efeito, não bastasse escolher adequadamente as políticas públicas, o Estado precisa potencializar seus recursos para que possa materializá-las, acrescenta Fields (2003, p. 253), o que pode se dar a partir da realocação de orçamentos domésticos, da atração de investimento estrangeiro direto, do aumento dos fluxos de ajuda e alívio da dívida. Tais alternativas indicam a simpatia do autor para com a lógica do mercado; todavia, é sempre válido lembrar 
que as práticas empresariais de dimensão transnacional se mostram, muitas vezes, agressivas e empenhadas em distanciar a noção de trabalho da premissa de dignidade.

$\mathrm{Na}$ contramão, as pequenas empresas, em razão do seu grande impacto na estrutura de empregos e autoempregos, podem ocupar lugar de destaque na promoção do trabalho decente (SACHS, 2004, p. 40-42). Dados da OIT (2015, p. 24), referentes à América Latina e ao Caribe, indicam, por exemplo, que as micro e pequenas empresas são majoritárias na região: do total de 11 milhões de empresas em 2015, as de pequeno e médio porte respondiam por mais de 10 milhões e geravam 46,6\% dos empregos; em contrapartida, as grandes empresas geravam menos de $17 \%$ dos empregos.

Contudo, muitos desses empreendimentos, por apresentarem produtividade reduzida, acabam por lançar mão de fatores escusos - como baixos salários, ausência de proteção social, e sonegação de impostos - para alcançar competitividade. Em outras palavras: "[...] para enfrentar os rigores do darwinismo social no mercado eles não têm outra solução a não ser mergulhar na informalidade." (SACHS, 2004, p. 40). Nessas circunstâncias, o Estado é duplamente prejudicado, porque deixa de arrecadar tributos, ao passo que precisa redobrar a luta contra a pobreza por meio de ações assistenciais, as quais drenam recursos que poderiam ser investidos na inclusão social pelo trabalho decente (SACHS, 2004, p. 40-41).

Por isso, na opinião de Sachs (2004, p. 40-42), a formalização das pequenas empresas representa medida prioritária quando se pretende promover o trabalho decente por intermédio do aludido setor. Paralelamente, é preciso que haja lugar para ações que consolidem os pequenos empreendimentos existentes, aumentem a produtividade e diminuam os índices de encerramento desse tipo de negócio; e, por último, deve-se considerar a expansão das empresas de pequeno porte em atividade, almejando a sua graduação para a categoria de médias empresas.

$\mathrm{Na}$ condução desse processo, o Estado deve pautar-se pelo "princípio do tratamento desigual dos desiguais", traçando ações afirmativas favoráveis aos pequenos empreendedores, capacitando-os para, com o tempo, enfrentar o mercado em condições de competitividade e de produtividade (SACHS, 2004, p. 41). Artifício semelhante é denominado "ajuste dos direitos e responsabilidades", na literatura sobre governança para o desenvolvimento sustentável, o qual pressupõe a intervenção do governo para ajustar as obrigações legais dos atores estabelecidos, facilitando algumas vias de desenvolvimento e dificultando o prosseguimento de outras (MEADOWCROFT, 2007, p. 119).

A despeito das medidas intervencionistas estruturadas para tornar competitivos os pequenos empreendimentos, merece atenção o papel do Estado na promoção do trabalho decente por meio do campo solidário da interação social, isto é, do empreendedorismo coletivo, haja vista despontarem dali muitas experiências inclinadas ao equilíbrio dos objetivos econômicos, sociais e ambientais.

Na lição de Singer (2002, p. 9), a construção de uma sociedade igual está consubstanciada na passagem para a economia solidária, "[...] outro modo de produção, cujos princípios básicos 
são a propriedade coletiva ou associada do capital e o direito à liberdade individual”, e no qual os participantes da atividade econômica cooperam entre si em vez de competir. Esse modelo alternativo de produção tem como protótipo de empresa a cooperativa, reunião de sócios com a mesma parcela de capital e o mesmo poder decisório, em coerência com a proposta-chave da economia solidária: associação entre iguais em substituição ao contrato entre desiguais.

Do ponto de vista econômico, a economia solidária oferece oportunidades como o acesso aos mercados e serviços de intermediação financeira e a criação de empregos - em todo mundo, as cooperativas asseguram 100 milhões de empregos, 20\% mais do que as empresas transnacionais. $\mathrm{Na}$ esfera social, suas raízes nos princípios da mutualidade, solidariedade e reciprocidade aproximam-na de ideias como a ampla proteção social, a redistribuição de renda e a maior observância às normas trabalhistas (ONU, 2014, p. 2-3).

Por tudo isso, vislumbra-se, na economia solidária, uma proposta promissora para a transição da economia informal para a economia formal, em condições de trabalho decente. Esse reconhecimento descortina um leque de possibilidades para a atuação do Estado, em apoio à matriz econômica solidária. Sousa, Rodrigues e Abrantes (2009, p. 9) sugerem:

a) a criação de programas de incentivo à cooperação e ao associativismo;

b) a capacitação dos sócios, visando à agregação de valor de seus produtos e serviços, e o conhecimento de normas associativas;

c) o oferecimento de assistência técnica adequada às características organizacionais dos empreendimentos;

d) o desenvolvimento de políticas para ampliar a demanda pelos produtos/serviços provenientes da economia solidária, e, por fim;

e) a estruturação de um sistema financeiro com condições diferenciadas para empreendimentos solidários, que disponha de linhas de financiamento e crédito.

Entretanto, pondera-se que, na condição de política de desenvolvimento, direcionada para um público historicamente excluído, "[...] a economia solidária demanda não só ações setoriais específicas, mas também ações transversais que articulem instrumentos de várias áreas do governo e do Estado (educação, saúde, meio ambiente, habitação, desenvolvimento econômico, saúde, tecnologia, crédito e financiamento etc.)” (PRAXEDES, 2009, p. 57). Elas não podem resumir-se, apenas, a medidas assistenciais ou compensatórias, devendo, sim, contribuir para a criação de um contexto efetivamente propulsor da emancipação e da sustentabilidade.

Outra questão que se apresenta diz respeito a como garantir a subsistência das ações para a economia solidária diante da rotatividade dos governos. Segundo Schiochet (2009, p. 57), a resposta é a institucionalização das políticas públicas de economia solidária, o que se realiza em dois aspectos: "sua caracterização de política de governo para política de Estado; e sua inserção no campo dos direitos, da constituição de sujeitos de direitos e das obrigações públicas (deveres do Estado para assegurar este conjunto de direitos).” (SCHIOCHET, 2009, p. 57). Transformar os programas e as ações em legislação parece, então, um bom caminho para vincular os governos. 
A formalização e o fortalecimento dos pequenos empreendimentos, o apoio à economia solidária e a adoção de políticas econômicas e sociais abrangentes são, como visto, providências indiretas e estruturais que o Estado pode tomar para promover o trabalho decente. Não se ignora, porém, o papel do ente estatal na regulamentação direta do trabalho, pela via legislativa e administrativa, assim como na posterior fiscalização do cumprimento dessas disposições.

No diagnóstico de Posthuma (2010, p. 57), o "enclave regulatório" - regulamentação pública que não compreende grupos de trabalhadores vulneráveis ou envolvidos em formas de trabalho menos visíveis e desprotegidas - é fenômeno típico da atualidade ${ }^{6}$. Esse tipo de lacuna pode ser constatado, por exemplo, quando não existe, em certo Estado, legislação específica para a proteção dos trabalhadores migrantes ou, pelo menos, legislações trabalhistas gerais alinhadas aos instrumentos protetivos internacionais nesse sentido, fato que é recorrente, a julgar pelo expressivo número de Estados-membros da OIT que sequer ratificaram a Convenção Internacional sobre Proteção dos Direitos de Todos os Trabalhadores Migrantes e de suas Famílias, de 1990 (CARTAXO; GOMES, 2017, p. 10).

Alerta-se, contudo, que nem toda inovação legislativa tem o condão de ampliar o rol de pessoas protegidas pelo direito do trabalho. Pelo contrário, um estudo sobre reformas legislativas laborais realizadas em 111 países, entre 2008 e 2014, demonstra que, do total de 643 alterações, $56 \%$ reduziram os níveis de regulamentação existentes. As tendências nos processos de reforma diferem amplamente entre as regiões, mas, no geral, elas têm sido mais frequentes nas economias desenvolvidas, nas quais a diminuição nos níveis de proteção se aproxima dos $65 \%$. A maioria dessas reformas, segundo a pesquisa, foi realizada sob a justificativa do desemprego experimentado na crise de 2008, mas, curiosamente, a taxa de emprego no ano seguinte à reforma, também analisada no documento, diminuiu ainda mais (ADASCALITEI; MORANO, 2015, p. 3-4). A interferência do Estado-nação, por meio da (des)regulamentação, nessa perspectiva, pode não acenar para "possibilidades", mas sim para verdadeiros desserviços à efetivação do trabalho decente, e, portanto, deve ser avaliada com cautela.

Outra face do "enclave regulatório" mencionado por Posthuma (2010, 64-66) compreende a dificuldade de monitoramento das condições de trabalho, seja nas grandes cadeias globais, seja na economia informal, em microempresas, nas áreas rurais afastadas e até no trabalho doméstico. Melhorias na estrutura da inspeção do trabalho, bem como na preparação das pessoas que a desempenham, são de grande importância especialmente para o êxito das metas que versam sobre o combate às piores formas de trabalho, como o trabalho forçado

6 Dentro do cenário pós-moderno, em que ganha corpo um direito transnacional, não se desconhece que a ausência de regulamentação estatal sobre determinada matéria pode ser superada com apoio em regulamentos transnacionais. No âmbito do Direito Internacional Econômico, particularmente, Webber Ziero (2018, p. 226) atenta para as possibilidades de interação entre fontes tradicionais e não tradicionais de direito internacional, com o envolvimento de uma pluralidade de atores estatais e não estatais, em dinâmicas de "[...] coordenação e complementariedade, conflito e concorrência normativos, contribuição para o desenvolvimento progressivo da lei, tradução e reconhecimento de demandas sociais”. Essa abertura, de acordo com o autor, encurta a distância entre as fontes tradicionais do Direito Internacional Econômico e as aspirações sociais, principalmente as de grupos marginalizados, que encontram nos regulamentos transnacionais um canal de expressão e de empoderamento (WEBBER ZIERO, 2018, p. 225-226). 
e o trabalho infantil. Afinal, promover trabalho decente também significa eliminar aquelas ocupações que são, reconhecidamente, indignas.

Elenca-se, entre os percalços a serem superados, a limitação da força de trabalho mobilizada para a fiscalização, a qual se situa, normalmente, abaixo dos padrões delineados pela OIT. Em segundo lugar, além da quantidade, a qualidade do pessoal e dos recursos deixa a desejar: "[...] os inspetores do trabalho frequentemente estão sobrecarregados, com falta de recursos e meios de viagem, mal pagos, sujeitos a subornos e pressão para não realizar inspeções que possam prejudicar o clima de investimento." (POSTHUMA, 2010, p. 64). Um terceiro desafio diz respeito às disparidades entre os países na organização da inspeção do trabalho e na definição da amplitude da fiscalização.

Nesse ponto, vale destacar que o Brasil possui estratégias de fiscalização e combate ao trabalho escravo reconhecidas como exemplares pela OIT. Uma delas é a existência do Grupo Especial de Fiscalização Móvel (GEFM) ${ }^{7}$, com atribuição para apurar denúncias de exploração do trabalho escravo no meio rural, liberar e assistir os trabalhadores, quando confirmadas, além de aplicar multas e tomar as providências para a responsabilização do explorador de mão de obra, tendo libertado mais de 45 mil pessoas em condições de escravidão desde a sua instituição em 1995 (ARBEX; GALIZA; OLIVEIRA, 2018, p. 115).

A "lista suja" é outra aclamada experiência brasileira. Trata-se, em linhas gerais, de cadastro de empregadores infratores, encaminhado aos ministérios e ao sistema bancário, a fim de impedir que as pessoas físicas e jurídicas autuadas se beneficiem de créditos públicos ou contratem com o Estado. Assim, a divulgação da lista consiste em mecanismo útil à repressão do trabalho escravo, produzindo impactos econômicos diretos e indiretos, por desgastar a imagem pública dos citados (ARBEX; GALIZA; OLIVEIRA, 2018, p. 118).

Tais iniciativas, embora venham sendo continuamente ameaçadas, no período de instabilidade que o Brasil atravessa, precisam ser conservadas e devem servir de inspiração para outros Estados. Uma das características da governança para o desenvolvimento sustentável, como recorda Meadowcroft (2007, p. 116), é, justamente, analisar e avaliar as práticas existentes e a eficácia das iniciativas políticas de outros Estados para desenvolver estratégias próprias semelhantes.

Caminhando-se para a conclusão, cabe verificar quais as recomendações que a Agenda 2030 faz, expressa e propriamente, para o Estado-nação quanto à efetivação dos ODS, que, por conseguinte, são prescrições voltadas também para a realização do objetivo de trabalho decente.

7 Atualmente, com a extinção do Ministério do Trabalho e Emprego, o funcionamento do GEFM passou a ser atribuição do Ministério da Economia, por meio da Subsecretaria de Inspeção do Trabalho (SIT) e no escopo da Divisão de Fiscalização para Erradicação do Trabalho Escravo (Detrae). As ações do Grupo são realizadas pela Auditoria Fiscal do Trabalho, em parceria com órgãos como a Polícia Rodoviária Federal, a Polícia Federal, o Ministério Público do Trabalho, o Ministério Público Federal e a Defensoria Pública da União. A Instrução Normativa no 91, de 2011, da então Secretaria de Inspeção do Trabalho, fornece as coordenadas para a atuação do GEFM (LYRA, 2014, p. 214-215). 
O documento incentiva "[...] os Estados-membros a realizarem avaliações regulares inclusivas de progresso nos níveis nacionais e subnacionais que sejam lideradas pelo país e orientadas para o país.” (ONU, 2015, p. 46). O processo de acompanhamento e avaliação, empreendido pelo ente estatal, demanda o desenvolvimento de indicadores, ou a melhoria dos existentes - por tratar-se de importante ferramenta para identificação das falhas e dos avanços na implementação da Agenda -, e a produção voluntária de relatórios a serem apresentados à ONU.

Os Estados podem recorrer também à criação de instituições, na estrutura do governo, para organizar o processo de transição para o desenvolvimento sustentável no nível nacional (ONU, 2015, p. 47). Essa ideia, ao que parece, foi bem recebida por uma parcela dos Estados comprometidos com o cumprimento da Agenda: em documento que reúne dados de 22 relatórios de acompanhamento nacional apresentados em 2016, verificou-se que muitos países criaram comissões próprias para os ODS, a exemplo de Bangladesh, do Brasil, da Colômbia, do México e da Ucrânia. Outros estão usando estruturas existentes, como é o caso da Alemanha, de Portugal, da Etiópia, da Estônia, da Finlândia etc. (UNDESA, 2017, p. 2-4).

As pistas aqui fornecidas, embora enfoquem o papel do Estado-nação, não desconsideram o fato de que os progressos na agenda do trabalho decente, no marco da Agenda 2030 da ONU, dependem, sobretudo, da articulação política transnacional de todos os atores. Ademais, há uma clara dependência entre os objetivos e as metas do projeto pós-2015, de modo que os resultados positivos na afirmação do trabalho decente estão condicionados ao enfrentamento de outros desafios previstos no itinerário, como o crescimento econômico sustentável, a educação de qualidade e a redução das desigualdades.

\section{CONCLUSÃO}

O fenômeno globalizante em curso desde a década de 1970 intensificou o processo de internacionalização do Estado-nação, inserindo-o cada vez mais em organizações interestatais e forçando-o a coordenar suas políticas com as dos outros Estados, no sentido de promover a gestão articulada dos problemas globais. O desenvolvimento é uma das temáticas que vem merecendo abordagem ampliada, consistindo a Agenda 2030 da ONU no projeto de governança global mais recente a ilustrar esse quadro.

Se, em algum momento do século XX, o desenvolvimento foi encarado como sinônimo de crescimento econômico e analisado tão somente por métricas quantitativas, à luz do itinerário pós-2015, faz par com o adjetivo sustentável para formar uma concepção aglutinadora de objetivos ambientais, econômicos e sociais, capazes de promover o bem-estar das pessoas e do planeta por meio da boa governança. Nesse pluridimensional conceito de desenvolvimento, o trabalho decente aparece como variável determinante para a afirmação da dignidade da pessoa humana e para o alcance da prosperidade individual e coletiva.

Concentrados no ODS 8 da Agenda 2030, o objetivo e as metas de trabalho decente, estudados neste texto, representam a síntese do mandato histórico da OIT sobre o tema, 
planeado especialmente a partir dos anos 1990. É certo que promover trabalho decente para todos, dentro dos padrões da OIT e diante das grandes transformações verificadas no mundo nas últimas décadas, exige a articulação das organizações internacionais, das organizações não governamentais, da iniciativa privada e, com destaque na presente pesquisa, do Estado-nação. A atuação do Estado nacional, nesse particular, encontra limites e também possibilidades.

Os limites, conforme evidenciados, decorrem, em última análise, da própria crise que o ente estatal atravessa na contemporaneidade. A influência exercida pelo mercado e seus poderosos atores restringe o papel do Estado às áreas econômica e social: para não afugentar as corporações transnacionais de seu território e, consequentemente, não afugentar investimentos e postos de trabalho, o Estado submete-se às condições por elas impostas. Não por acaso, a expansão das redes globais de produção tem motivado reformas estruturais no sentido de liberar as regulamentações sobre a área econômica, promovendo o sintomático enfraquecimento das políticas de bem-estar social e a crescente limitação da capacidade estatal para projetar, materializar e gerir políticas de trabalho.

Apesar dessas limitações, vislumbra-se que o Estado-nação, dentro das possibilidades que ainda lhe restam, deve procurar minimizar o impacto da atuação das transnacionais sobre a realidade nacional. Para tanto, e pensando particularmente na promoção do trabalho decente, o presente estudo elencou, entre outras medidas, a adoção de políticas públicas específicas, e outras amplamente consideradas (econômicas e sociais), cujos reflexos se farão sentir no âmbito laboral; a formalização e o fortalecimento dos pequenos empreendimentos e o apoio às iniciativas de economia solidária, por representarem vias que operam com uma racionalidade mais sensível à questão da dignidade no trabalho; a modernização das legislações para compreender, no arcabouço protetivo trabalhista, a nova gama de trabalhadores e os novos direitos decorrentes das relações de trabalho contemporâneas; a potencialização dos mecanismos de inspeção do trabalho; e, por fim, o atendimento das recomendações que a Agenda 2030 dirige expressamente ao Estado, como a criação de instituições, na estrutura do governo, para organizar o processo de transição para o desenvolvimento sustentável no nível nacional.

Portanto, conclui-se que, embora o Estado-nação tenha possibilidades de avançar na efetivação do trabalho decente, como quer a Agenda 2030 da Organização das Nações Unidas, esse processo está condicionado, em alguma medida, à ação convergente de outros atores, mormente os que representam interesses econômicos. Esse é o grande desafio que se abre, nesse grandioso projeto civilizatório da ONU, até 2030.

\section{REFERENCIAS}

ABRAMO, Laís. Trabalho decente: o itinerário de uma proposta. Bahia análise e Dados, Salvador, v. 20, n. 2/3, p. 151-171, jul./set. 2010. Disponível em: https://s3.amaz onaws.com/academia.edu.documents/6736840/artigo_trabalho_decente.pdf?AWSAc cessKeyId=AKIAIWOWYGZ2Y53UL3A\& Expires $=1537481838 \&$ Signature $=$ bKDeXae BsUHN2JC1\%2Bp2wLz50POQ\%3D\&response-content disposition=inline\%3B\%20 
filename\%3DTrabalho_decente_dinamica_populacional_e.pdf\#page=8. Acesso em: 27 jun. 2018.

ADASCALITEI, Dragos; MORANO, Clemente Pignatti. Labour Market reforms since the crisis: drivers and consequences. Geneva: International Labour Office, Research Department, 2015. Disponível em: www.intersindicalcentral.com.br/wpcontent/uploads/2017/09/Drivers-and-effects-of-labour-market-reforms-Evidence-from-anovel-policy-compendium.pdf. Acesso em: 22 jul. 2018.

ALBUQUERQUE, Ana Paula Freitas de. O mundo do trabalho na era da globalização. In: ALBUQUERQUE, Ana Paula Freitas de et al. (org.). Estudos de direito do trabalho e processo do trabalho. Passo Fundo: IMED, 2006. p. 21-57.

ALVES, Giovanni. Dimensões da precarização do trabalho: ensaios de Sociologia do Trabalho. Bauru: Canal 6, 2013.

ALVES, Giovanni. Dimensões da reestruturação produtiva: ensaios de Sociologia do Trabalho. 2. ed. Bauru: Canal 6, 2007.

ALVES, Giovanni. Trabalho, subjetividade e capitalismo manipulatório: o novo metabolismo social do trabalho e a precarização do homem que trabalha. Revista Estudos do Trabalho, Marília, v. 5, n. 8, p. 1-31, 2011. Disponível em: https://s3.amazonaws.com/ academia.edu.documents/40057419/Trabalho__subjetividade_e_capitalismo_manipulatorio_ALVES.pdf?AWSAccessKeyId=AKIAIWOWYYGZ2Y53UL3A\&Expires=15285836 03\& Signature $=\mathrm{cdBjg} 2 \mathrm{VzFWuKB} 5 \mathrm{dJF} 5 \mathrm{NsUq}$ lhr8g\%3D\& responsecontentdisposition=inli ne\%3B\%20filename\%3DTrabalho_subjetividade_e_capitalismo_man.pdf. Acesso em: 15 maio 2018.

ANTUNES, Ricardo. Adeus ao trabalho?: ensaios sobre a metamorfose e a centralidade do mundo do trabalho. 14. ed. São Paulo: Cortez, 2010.

ARBEX, Alexandre; GALIZA, Marcelo; OLIVEIRA, Tiago. A política de combate ao trabalho escravo no período recente. Mercado de trabalho: boletim do Ipea, Brasília, n. 64, p. 111-137, 2018. Disponível em: http://repositorio.ipea.gov.br/handle/11058/8385. Acesso em: 22 jul. 2018.

ARENDT, Hannah. A condição humana. Tradução Roberto Raposo. 10. ed. Rio de Janeiro: Forense Universitária, 2007.

AZEVEDO NETO, Platon Teixeira de. O trabalho decente como um direito humano. São Paulo: LTr, 2015.

BENEDEK, Wolfgang. Muti-stakeholderism in the development of International Law. In: FASTENRATH, Urilch et al. (ed.). From bilateralism to community interest: essays in 
honour of Judge Bruno Simma. Oxford University Press: New York, 2011. p. 201-210. Disponível em: https://static.unigraz.at/fileadmin/rewiinstitute/Voelkerrecht/P/Publikationen_Benedek/MultiStakeholderism_in_the_Development_of_International_law__2010_. pdf. Acesso em: 13 out. 2019.

BROWNE, Stephen. Sustainable development goals and UN goal-setting. New York: Routledge, 2017.

CARTAXO, Marina Andrade; GOMES, AnaVirgínia Moreira. As Convenções da OIT sobre proteção aos direitos do trabalhador migrante. Revista Brasileira de Direito Internacional, Florianópolis, v. 2, n. 2, p. 01-19, 2017. Disponível em: indexlawreview.org/index. php/direitointernacional/article/view/1645. Acesso em: 24 jul. 2018.

CASTELLS, Manuel. The new public sphere: global civil society, communication networks, and global governance. Annals of the American Academy of Political and Social Science, v. 616, p. 78-93, Mar. 2008. Disponível em: https://pdfs.semanticscholar.org/69cb/3c 066b658c660c33aeb680766537d9da76ff.pdf?_ga=2.265797967.1966808360.15709057752088859030.1570905775. Acesso em: 12 out. 2019.

ECOSOC - ECONOMIC AND SOCIAL COUNCIL. Commission on Human Rights: seventh session. Summary record of the two hundred and twentieth meeting. Geneva, 30 April 1951. Disponível em: https://uvallsc.s3.amazonaws.com/travaux/s3fs-public/ECN_4-SR_220_0.pdf?null. Acesso em: 9 out. 2019.

FIELDS, Gary S. Decent Work and development policies. International Labour Review, v. 142, n. 2, p. 239-262, 2003. Disponível em: https://digitalcommons.ilr.cornell.edu/cgi/ viewcontent.cgi? referer=https://www.google.cco.br/\&httpsredir=1\&article=1263\& context =articles. Acesso em: 18 jul. 2018.

G20. Innovation and Inclusive Growth: Decent Work, Enhanced Employability and Adequate Job Opportunities. 2016. Disponível em: https://www.ilo.org/wcmsp5/groups/public/m dgreports/mdcomm/documents/statement/wcms_499403.pdf. Acesso em: 11 put. 2019.

GIL, Antonio Carlos. Métodos e técnicas de pesquisa social. 6. ed. São Paulo: Atlas, 2008.

HUMAN RIGHTS COUNCIL. Guiding Principles on Business and Human Rights. New York: Office of the United Nations High Commissioner for Human Rights, 2011. Disponível em: https://www.ohchr.org/documents/publications/GuidingprinciplesBusinesshr_eN.pdf. Acesso em: 13 out. 2019.

INTERNATIONAL LABOUR OFFICE (ILO). Global estimates of child labour. Geneva: ILO, 2017a. Disponível em: http://www.ilo.org/wcmsp5/groups/public/@dgreports/@ dcomm/documents/publication/wcms_575499.pdf. Acesso em: 12 jan. 2018. 
INTERNATIONAL LABOUR OFFICE (ILO). Global estimates of modern slavery: forced labour and forced marriage. Geneva: ILO, 2017b. Disponível em: http://www.ilo.org/ wcmsp5/groups/public/@dgreports/@dcomm/documents/publication/wcms_575479.pdf. Acesso em: 12 jan. 2018.

INTERNATIONAL LABOUR OFFICE (ILO). Women at Work: trends 2016. Geneva: ILO, 2016. Disponível em: http://www.ilo.org/wcmsp5/groups/public/-.dgreports/-. dcomm/publ/documents/publication/wcms_457317.pdf. Acesso em: 1 jun. 2018.

INTERNATIONAL LABOUR ORGANIZATION. 105th Session of the International Labour Conference. Resolution concerning decent work in global supply chains, adopted on 10 June 2016. Disponível em: https://www.ilo.org/wcmsp5/groups/public/--ed_norm/ -relconf/documents/meetingdocument/wcms_497555.pdf. Acesso em: 9 out. 2019.

INTERNATIONAL LABOUR ORGANIZATION. Tripartite Declaration of Principlesconcerning Multinational Enterprises and Social Policy. Geneva: International Labour Office, March 2017. Disponível em: https://www.ilo.org/wcmsp5/groups/public/-.-ed_ emp/--emp_ent/-multi/documents/publication/wcms_094386.pdf. Acesso em: 14 out. 2019.

INTERNATIONAL LABOUR ORGANIZATION (ILO). Questions and answers on forced labour. 2012. Disponível em: https://www.ilo.org/global/about-the-ilo/newsroom/ news/WCMS_1181922/lang--en/index.htm. Acesso em: 30 maio 2018.

LAZZARESCHI, Noêmia. Globalização da economia e reestruturação produtiva: as repercussões sociais das novas configurações: as repercussões sociais das novas configurações do trabalho. Ciências Sociais Unisinos, São Leopoldo, v. 54, n. 1, p. 93-105, 2018. Disponível em: https://www.revistas.unisinos.br/index.php/ciencias_sociais/article/view/ csu.2018.54.1.09. Acesso em: 29 maio 2018.

LYRA, Alexandre Rodrigo T. da C. O enfrentamento do trabalho em condição análoga à de escravo. Estud. av., São Paulo, v. 28, n. 81, p. 213-227, ago. 2014. Disponível em: http://www.scielo.br/scielo.php?pid=S010340142014000200015\&script=sci_ arttext\&tlng=es. Acesso em: 9 out. 2019.

MAEDA, Patrícia. A era dos zero Direitos: trabalho decente, terceirização e contrato zero-hora. São Paulo: LTr, 2017.

MEADOWCROFT, James. Who is in charge here? Governance for sustainable development in a complex world. Journal of Environmental Policy \& Planning, v. 9, n. 3/4, p. 299-314, 2007. Disponível em: https://www.researchgate.net/publication/248926024_ Who_is_in_Charge_here_Governance_for_Sustainable_Development_in_a_Complex_ World. Acesso em: 3 mar. 2018. 
OLSSON, Giovanni. Uma leitura não-liberal das políticas do trabalho na era da globalização. Sequência: Estudos jurídicos e políticos, Florianópolis, v. 23, n. 45, p. 67-96, dez. 2002. Disponível em: https://search.proquest.com/openview/Oefd13aed2b8dfca61bafd2c4 fd56cd/1?pq-origsite=gscholar\&cbl=1796400. Acesso em: 14 jun. 2018.

OLSSON, Giovanni. A sociedade internacional contemporânea e o papel dos atores globais no mundo do trabalho. In: SARLET, Ingo Wofgang; MELLO FILHO, Luiz Philippe Vieira de; FRAZÃO, Ana de Oliveira (org.). Diálogos entre o direito do trabalho e o direito constitucional. São Paulo: Saraiva, 2014. p. 589-563.

ORGANIZAÇÃO DAS NAÇÕES UNIDAS (ONU). Economia Social e Solidária e o Desafio do Desenvolvimento Sustentável: documento de posicionamento pela Força-Tarefa de Interagências das Nações Unidas sobre Economia Social e Solidária (FTESS). 2014. Disponível em: unsse.org/wp-content/uploads/2014/08/PositionPaper_TSFFE_Port1.pdf. Acesso em: 21 jul. 2018.

ORGANIZAÇÃO DAS NAÇÕES UNIDAS (ONU). Transformando Nosso Mundo: a Agenda 2030 para o Desenvolvimento Sustentável. 2015. Disponível em: http://www. br.undp.org/content/dam/brazil/docs/agenda2030/undp-br-Agenda2030-completo-pt-br-2016.pdf. Acesso em: 10 set. 2017.

ORGANIZAÇÃO DAS NAÇÕES UNIDAS (ONU). O Futuro Que Queremos: Declaração Final da Conferência das Nações Unidas sobre Desenvolvimento Sustentável (Rio + 20). 2012. Disponível em: http://www2.mma.gov.br/port/conama/ processos/61AA3835/O-Futuro-que-queremos1.pdf. Acesso 10 set. 2017.

ORGANIZAÇÃO INTERNACIONAL DO TRABALHO (OIT). Constituição da Organização Internacional do Trabalho (OIT) e seu anexo (Declaração de Filadélfia). 1944. Disponível em: http://www.ilo.org/wcmsp5/groups/public/-mamericas/-ro-lima/--ilo-brasilia/documents/genericdocument/wcms_336957.pdf. Acesso em: 1 jun. 2018.

ORGANIZAÇÃO INTERNACIONAL DO TRABALHO (OIT). Declaração da OIT sobre os Princípios e Direitos Fundamentais no Trabalho. 1998. Disponível em: https:// www.ilo.org/public/english/standards/declaration/declaration_portuguese.pdf. Acesso em: 13 maio 2018.

ORGANIZAÇÃO INTERNACIONAL DO TRABALHO (OIT). Uma aliança global contra o trabalho forçado: relatório global do seguimento da Declaração da OIT sobre Princípios e Direitos Fundamentais no Trabalho. Tradução Edilson Alkmin Cunha. Genebra: ILO, 2005. Disponível em: https://www.reporterbrasil.com.br/documentos/relatorio_global2005.pdf. Acesso em: 30 maio 2018.

ORGANIZACIÓN INTERNACIONAL DEL TRABAJO (OIT). Memoria del Director 
General: trabajo decente. 87ª reunión, Ginebra, junio de 1999. Disponível em: https:// www.ilo.org/public/spanish/standards/relm/ilc/ilc87/rep-i.htm. Acesso em: 13 fev. 2020. ORGANIZACIÓN INTERNACIONAL DEL TRABAJO (OIT). Panorama temático laboral: pequeñas empresas, grandes brechas. Empleo y condiciones de trabajo em las MYPE de América Latina y el Caribe. Oficina Regional para América Latina y el Caribe, Lima, 2015. Disponível em: https://www.ilo.org/wcmsp5/groups/public/-mamericas/-_ro lima/ documents/publication/wcms_398103.pdf. Acesso em: 20 jul. 2018.

PESSOA, Flavia Moreira Guimarães; SANTOS, Mariana Farias. O trabalho no call center: um olhar através do trabalho decente. São Paulo: LTr, 2017.

POSTHUMA, Anne. Beyond 'regulatory enclaves': challenges and opportunities to promote decente work in global production networks. In: POSTHUMA, Anne; NATHAN, Dev. (ed.). Labour in global production networks in India. New York: Oxford University Press, 2010. p. 57-80. Disponível em: https://www.ilo.org/legacy/english/protection/travail/pdf/rdwpaper43c.pdf. Acesso em: 10 jul. 2018.

PRAXEDES, Sandra. Políticas Públicas de Economia Solidária: novas práticas, novas metodologias. Mercado de trabalho: boletim do Ipea, Brasília, n. 39, p. 57-62, 2009. Disponível em: repositorio.ipea.gov.br/handle/11058/4069. Acesso em: 22 jul. 2018.

PRENKERT, Jamie Darin; SHACKELFORD, Scott J. Business, Human Rights, and the Promise of Polycentricity. Vanderbilt Journal of Transnational Law, Nashville, v. 47, p. 451-500, 2014. Disponível em: https://www.vanderbilt.edu/wpcontent/uploads/sites/78/ Prenkert-Final.pdf. Acesso em: 12 out. 2019.

RODGERS, Gerry. El trabajo decente como uma meta para la economía global. Boletín Técnico Interamericano de Formación Profesional, Montevideo, n. 153, p. 9-28, 2002. Disponível em: https://www.oitcinterfor.org/sites/default/files/file_articulo/rodger.pdf. Acesso em: 12 jul. 2018.

SACHS, Ignacy. Inclusão social pelo trabalho decente: oportunidades, obstáculos, políticas públicas. Estudos avançados, São Paulo, v. 18, n. 51, p. 23-49, 2004. Disponível em: www. revistas.usp.br/eav/article/view/9998. Acesso em: 10 jul. 2018.

SACHS, Jeffrey. The Age of Sustainable Development. New York: Columbia University Press, 2017.

SCHIOCHET, Valmor. Institucionalização das políticas publicas de economia solidária: breve trajetória e desafios. Mercado de trabalho: boletim do Ipea, Brasília, n. 40, p. 55 59, 2009. Disponível em: repositorio.ipea.gov.br/bitstream/11058/4085/1/bmt40_08_ ECONS_institucionalizacao.pdf. Acesso em: 22 jul. 2018. 
SINGER, Paul. Introdução à Economia Solidária. São Paulo: Fundação Perseu Abramo, 2002.

SOUSA, Sydneia R.; RODRIGUES, Luciene; ABRANTES, Sidneia Maria Souza. A economia solidária no âmago de resistências e lutas sociais contra o desemprego: o papel do Estado na criação de políticas públicas. In: JORNADA INTERNACIONAL DE POLÍTICAS PÚBLICAS, 4., 2009, São Luís. Anais eletrônicos [...]. São Luís: UFMA, 2009. Disponível em: www.joinpp.ufma.br/jornadas/joinppIV/eixos/9_estados-e-lutas-sociais/a-economia-solidaria-no-amago-de-resistencias-e-lutas-sociais-contra-o-desemprego-e-a-pobreza.pdf. Acesso em: 20 jul. 2018.

STANDING, Guy. The ILO: an agency for globalization? Development and Change, v. 39, n. 3, p. 355-384, 2008. Disponível em: http://www.globallabour.info/en/2009/01/ the_ilo_an_agency_for_globaliz.html. Acesso em: 16 maio 2018.

UNITED NATIONS. General Assembly. We, the peoples: civil society, the United Nations and global governance. Report of the Panel of Eminent Persons on United NationsCivilSociety Relations. 2004. Disponível em: http://unpan1.un.org/intradoc/groups/ public/documents/un-dpadm/unpan041831.pdf. Acesso em: 13 out. 2019.

UNITED NATIONS DEPARTMENT OF ECONOMIC AND SOCIAL AFFAIRS (UNDESA). Overview of institutional arrangements for implementing the 2030 Agenda at national level. 2017. Disponível em: http://sustainabledevelopment.un.org/content/ documents/10735Updated_Issues_Brief_rer10_1_March_2017.pdf. Acesso em: 22 jul. 2018

UNITED NATIONS DEVELOPMENT PROGRAMME (UNDP). Human Development Report 2016: human development for everyone. New York: UNDP, 2016. Disponível em: http://hdr.undp.org/sites/default/files/2016_human_development_report.pdf. Acesso em: 10 jan. 2018.

UNITED NATIONS. The Millennium Goals Report 2015. New York: UN Publications, 2015. Disponível em: https://nacoesunidas.org/wp-content/uploads/2015/07/MDG-2015June-25.pdf. Acesso em: 14 jul. 2018.

VILLAS BÔAS, Bruno. Informalidade foi o motor do emprego no país em 2017, aponta IBGE. Valor Econômico, São Paulo, 31 jan. 2018. Disponível em: www.valor.com.br/ brasil/5295309/informalidade-foi-o-motor-do-emprego-no-pais-em-2017-aponta-ibge. Acesso em: 4 jun. 2018.

WEBBER ZIERO, Gabriel. The potential of transnational regulations: the interactions between traditional and non-traditional sources of International Economic Law. In: AMTENBRINK, Fabian; PRÉVOST, Denise; WESSEL, Ramses A. (ed.). Netherlands Yearbook of International Law 2017. Netherlands: Springer, 2018. p. 207-229. 


\section{NOTA}

$\mathrm{O}$ artigo intitulado "Os limites e as possibilidades do Estado-nação na promoção do trabalho decente no marco da Agenda 2030 da Organização das Nações Unidas" é resultado de pesquisa realizada por ambos os coautores, no âmbito do Grupo de Pesquisa Relações Internacionais, Direito e Poder, da Unochapecó. A delimitação do tema e a definição dos objetivos deram-se em conjunto, em reuniões presenciais. O coautor Giovanni Olsson, na condição de orientador acadêmico, contribuiu com a estruturação do trabalho, indicação de bibliografia, com parte da escrita (elementos pré-textuais, introdução e conclusão), e com as revisões teóricas e gramaticais. A coautora Tuana Paula Lavall, na condição de orientanda, contribuiu com indicação de bibliografia e com a parte remanescente da escrita (tópicos 2 e 3). 